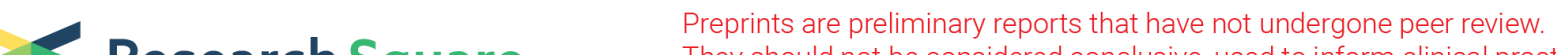 Research Square They should not be considered conclusive, used to inform clinical practice, or referenced by the media as validated information.
}

\section{Development of A One-Step Multiplex qRT-PCR Assay For Detection of African Swine Fever Virus, Classical Swine Fever Virus And Atypical Porcine Pestivirus}

Huixin Liu

Guangxi University

Kaichuang Shi ( $\nabla$ shikaichuang@126.com )

Guangxi Center for Animal Disease Control and Prevention

Jing Zhao

Guangxi University

Yanwen Yin

Guangxi Center for Animal Disease Control and Prevention

\section{Yating Chen}

Guangxi University

Hongbin Si

Guangxi University

\section{Sujie Qu}

Guangxi Center for Animal Disease Control and Prevention

\section{Feng Long}

Guangxi Center for Animal Disease Control and Prevention

\section{Wenjun Lu}

Guangxi Center for Animal Disease Control and Prevention

\section{Research Article}

Keywords: African swine fever virus (ASFV), Classical swine fever virus (CSFV), Atypical porcine pestivirus (APPV), Multiplex qRT-PCR

Posted Date: May 27th, 2021

DOl: https://doi.org/10.21203/rs.3.rs-496292/v1

License: (c) (1) This work is licensed under a Creative Commons Attribution 4.0 International License. Read Full License 
Version of Record: A version of this preprint was published at BMC Veterinary Research on January 18th, 2022. See the published version at https://doi.org/10.1186/s12917-022-03144-4. 


\section{Abstract}

Background: African swine fever virus (ASFV), classical swine fever virus (CSFV) and atypical porcine pestivirus (APPV) have caused great economic losses to the swine industry in China. Since there exist coinfections of ASFV, CSFV and APPV in certain pig herds, it is necessary to accurately and differentially detect these pathogens in the fields. In this study, a one-step multiplex real-time quantitative reverse transcription-polymerase chain reaction (multiplex qRT-PCR) was developed for simultaneous and differential detection of ASFV, CSFV and APPV.

Results: The developed one-step multiplex qRT-PCR was able to specifically detect ASFV, CSFV and APPV, but could not amplify other viruses, including porcine circovirus type 2 (PCV2), pseudorabies virus (PRV), porcine reproductive and respiratory syndrome virus (PRRSV), foot-and-mouth disease virus (FMDV), porcine parvovirus (PPV), porcine epidemic diarrhea virus (PEDV), transmissible gastroenteritis virus (TGEV), porcine rotavirus (PRoV), porcine deltacoronavirus (PDCoV), border disease virus (BDV), bovine viral diarrhea virus type 1 (BVDV-1), BVDV-2 and so on. The detection limit of the assay was $2.52 \times 10^{1}$ copies/ $\mu \mathrm{L}$ for ASFV, CSFV and APPV. Repeatability test using standard plasmids showed that the coefficients of variation of the intra- and inter-assay were less than $2 \%$. The detection of 509 clinical samples collected in Guangxi Province, Southern China from October 2018 to December 2020 showed that the positive rates of ASFV, CSFV and APPV were $45.58 \%, 12.57 \%$ and $3.54 \%$, respectively, while the co-infection rates of ASFV and CSFV, ASFV and APPV, CSFV and APPV were $4.91 \%, 1.38 \%, 0.98 \%$, respectively. Phylogenetic analysis based on the nucleotide sequences of partial ASFV p72 gene showed that all ASFV strains from Guangxi Province, Southern China belonged to genotype I and II.

Conclusion: A one-step multiplex qRT-PCR with high specificity, sensitivity, accuracy and repeatability was successfully developed for simultaneous and differential detection of ASFV, CSFV and APPV.

\section{Background}

African swine fever virus (ASFV) is an enveloped double-stranded DNA virus and the only member of genus Asfivirus in the family Asfarvirifae [1]. ASFV can cause African swine fever (ASF), a notifiable disease to the World Organization for Animal Health (OIE), which is characterized by high fever, extensive hemorrhage, pulmonary edema and intensive necrosis of lymphoid tissue, with high morbidity and mortality [2]. ASF was firstly emerged in Kenya in the 1920s, then spread to Europe in 1957, and further extended over the Caucasus region and into southern Russia in 2007 [3, 4], and recently introduced into China in August 2018 [5]. The disease spread rapidly over the country in short time and severely disrupted Chinese swine industry [6].

Classical swine fever virus (CSFV) is an enveloped single-stranded, positive-sense RNA virus that belongs to the Pestivirus genus of the Flaviviridae family [7]. CSFV can cause classical swine fever (CSF), another notifiable disease to the OIE, which is characterized by high fever, leukopenia, extensive hemorrhage, convulsion and constipation or diarrhea, with high morbidity and mortality [8]. CSF was first reported in 
Ohio, USA in 1833, and nowadays, CSF is still prevalent in many countries in the world $[9,10]$. Although Chinese C-strain vaccine of CSFV was developed in 1950s and has been widely using since then in the fields, CSF is still sporadic in many regions in China $[11,12]$.

Atypical porcine pestivirus (APPV), together with CSFV, border disease virus (BDV), bovine viral diarrhea virus 1 (BVDV-1) and BVDV-2, belongs to the Pestivirus genus of the Flaviviridae family [13]. It was first discovered in USA in 2015 [14], and then reported in many countries in America, Asia and Europe [13, 15]. APPV was demonstrated to be the causative agent of type A-II congenital tremor (CT) in newborn piglets, characterized by generalized body shaking with variable degrees of hypomyelination in brain and spinal cord [14, 16], which is similar to type A-I CT caused by CSFV [17].

ASFV, CSFV and APPV are still prevalent in many countries and cause huge economic losses to the swine industry worldwide. ASF and CSF show similar clinical symptoms and pathological changes in the fields, such as high fever, leukopenia, extensive hemorrhage, constipation or diarrhea, and high mortality [2, 8]. Type A-II CT caused by APPV shows similar clinical manifestations with type A-I CT caused by CSFV in newborn piglets $[16,17]$. So, it is very difficult to distinguish these diseases in the fields sometimes. Furthermore, ASFV, CSFV and APPV are epidemic in many countries at the same time, and co-infection of ASFV, CSFV and/or APPV in pig herds can not be ruled out $[18,19]$. Therefore, it is very important to differentially detect these pathogens in the laboratory. Currently, several differential polymerase chain reaction (PCR)/reverse transcription (RT)-PCR and real-time quantitative PCR (qPCR)/qRT-PCR assays have been developed for detection of ASFV [20, 21], CSFV [22, 23], APPV [24], ASFV/CSFV [25, 26] and ASFV/CSFV/APPV [18]. However, no qRT-PCR assay capable of simultaneous and differential detection of ASFV, CSFV and APPV has been reported until now. The objective of this study was to develop a specific, sensitive and reproducible one-step multiplex qRT-PCR for simultaneous and differential detection of ASFV, CSFV and APPV.

\section{Results}

\section{Construction of standard plasmids}

The target fragments of ASFV p72 gene, CSFV 5' untranslated region (UTR) and APPV 5'UTR were amplified by PCR/RT-PCR, purified and ligated to pMD18-T vector (TaKaRa, Dalian, China), and then transferred into E. coli $\mathrm{DH} 5$ a competent cells. The positive clones were cultured and the plasmid constructs were extracted and determined their concentrations. As a result, the original concentrations of the three standard plasmids named as p-ASFV, p-CSFV and p-APPV were $2.65 \times 10^{10}$ copies $/ \mu \mathrm{L}, 2.52 \times$ $10^{10}$ copies $/ \mu \mathrm{L}, 3.02 \times 10^{10}$ copies $/ \mu \mathrm{L}$, respectively, and were used as positive standard plasmids for optimization and sensitivity detection of the multiplex qRT-PCR.

\section{Optimal parameters of the multiplex qRT-PCR}

After optimization, the reaction conditions, including annealing temperature, concentrations of primers and probes and so on were acquired, and the parameters for the developed multiplex qRT-PCR were 
selected as follows: $10 \mu \mathrm{L}$ of $2 \times$ One Step RT-PCR Buffer III (TaKaRa, Dalian, China), $0.4 \mu \mathrm{L}$ of Ex Taq HS $(5 \mathrm{U} / \mu \mathrm{L})$ (TaKaRa, Dalian, China), $0.4 \mu \mathrm{L}$ of PrimeScript RT Enzyme Mix II (RNA/DNA) (TaKaRa, Dalian, China), $0.4 \mu \mathrm{L}$ of each of ASFV, CSFV and APPV primers (20 pmol/ $\mu \mathrm{L}), 0.5 \mu \mathrm{L}$ of ASFV-p72-P (20 pmol/ $\mu \mathrm{L}), 0.4 \mu \mathrm{L}$ of CSFV-5'UTR-P ( $20 \mathrm{pmol} / \mu \mathrm{L}), 0.3 \mu \mathrm{L}$ of APPV-5'UTR-P $(20 \mathrm{pmol} / \mu \mathrm{L}), 2.0 \mu \mathrm{L}$ of total DNA/RNA and distilled water to a total volume of $20 \mu \mathrm{L}$. The amplification parameters were as follows: reverse transcription at $42^{\circ} \mathrm{C}$ for $5 \mathrm{~min}$, and inactivation at $95^{\circ} \mathrm{C}$ for $10 \mathrm{~s}$; and then 40 cycles of denaturation at $95^{\circ} \mathrm{C}$ for $5 \mathrm{~s}$, annealing and extension at $59^{\circ} \mathrm{C}$ for $34 \mathrm{~s}$. The fluorescent signals were determined at the end of each cycle.

\section{Standard curves of the multiplex qRT-PCR}

To make the standard curves of the multiplex qRT-PCR, the standard plasmids of p-ASFV, p-CSFV and pAPPV were 10-fold serially diluted and mixed together for a final concentrations of each plasmid from $2.52 \times 10^{8}$ to $2.52 \times 10^{0}$ copies/ $\mu \mathrm{L}$ per reaction. As a result, all the $\mathrm{R}^{2}$ of ASFV, CSFV and APPV standard curves were over 0.999 , showing good linear relationship between initial template concentration and the threshold cycle (Ct) values (Fig. 1).

\section{Specificity of the multiplex qRT-PCR}

To evaluate the specificity of the assay, the RNAs/DNAs of ASFV, CSFV, APPV, and 12 other viruses, including porcine circovirus type 2 (PCV2), pseudorabies virus (PRV), porcine reproductive and respiratory syndrome virus (PRRSV), foot-and-mouth disease virus (FMDV), porcine parvovirus (PPV), porcine epidemic diarrhea virus (PEDV), transmissible gastroenteritis virus (TGEV), porcine rotavirus (PRoV), porcine deltacoronavirus (PDCoV), BVDV-1, BVDV-2 and BDV, were used as templates for the multiplex qRT-PCR. As a result, ASFV, CSFV and APPV showed specific amplification curves, while all 12 other viruses did not show any fluorescent signal and amplification curve, showing high specificity of the assay (Fig. 2).

\section{Sensitivity of the multiplex qRT-PCR}

The standard plasmids of p-ASFV, p-CSFV and p-APPV were 10-fold serially diluted from $2.52 \times 10^{8}$ to $2.52 \times 10^{0} \mathrm{copies} / \mu \mathrm{L}$ (final reaction concentrations: from $2.52 \times 10^{7}$ copies $/ \mu \mathrm{L}$ to $2.52 \times 10^{-1} \mathrm{copies} /$ $\mu \mathrm{L}$ )and used to determine the sensitivity of the multiplex qRT-PCR. As a result, the detection limit of the multiplex qRT-PCR was $2.52 \times 10^{0}$ copies/ $\mu \mathrm{L}$ for ASFV, CSFV and APPV per reaction (Fig. 3).

\section{Repeatability of the multiplex qRT-PCR}

To evaluate the repeatability of the assay, three concentrations of each standard plasmid in the mixtures with a final reaction concentrations of $2.52 \times 10^{7}, 2.52 \times 10^{5}$ and $2.52 \times 10^{3}$ copies $/ \mu \mathrm{L}$ were used as templates for intra- and inter-assay. The results showed that the coefficients of variation (CV) of the $\mathrm{Ct}$ values of intra- and inter-assay were less than $2 \%$ (Table 2), indicating high repeatability of the assay. 
Table 2 Repeatability analysis of the multiplex qRT-PCR

\begin{tabular}{|c|c|c|c|c|c|c|c|}
\hline \multirow[t]{2}{*}{ Plasmid } & \multirow{2}{*}{$\begin{array}{l}\text { Concentration } \\
\text { (copies/ } \mu \mathrm{L} \text { ) }\end{array}$} & \multicolumn{3}{|c|}{ Ct values of intra-assay } & \multicolumn{3}{|c|}{ Ct value of inter-asssay } \\
\hline & & $\nabla X$ & SD & CV (\%) & $\nabla X$ & SD & CV (\%) \\
\hline \multirow[t]{3}{*}{ p-ASFV } & $2.52 \times 10^{3}$ & 27.847 & 0.370 & 1.329 & 27.942 & 0.379 & 1.356 \\
\hline & $2.52 \times 10^{5}$ & 20.738 & 0.168 & 0.810 & 20.747 & 0.207 & 0.998 \\
\hline & $2.52 \times 10^{7}$ & 13.845 & 0.166 & 1.199 & 13.725 & 0.124 & 0.903 \\
\hline \multirow[t]{3}{*}{ P-CSFV } & $2.52 \times 10^{3}$ & 28.001 & 0.153 & 0.546 & 27.946 & 0.186 & 0.666 \\
\hline & $2.52 \times 10^{5}$ & 20.359 & 0.200 & 0.982 & 20.457 & 0.239 & 1.168 \\
\hline & $2.52 \times 10^{7}$ & 13.109 & 0.156 & 1.190 & 13.076 & 0.088 & 0.673 \\
\hline \multirow[t]{3}{*}{ P-APPV } & $2.52 \times 10^{3}$ & 27.328 & 0.152 & 0.556 & 27.314 & 0.137 & 0.502 \\
\hline & $2.52 \times 10^{5}$ & 19.125 & 0.267 & 1.396 & 19.128 & 0.207 & 1.082 \\
\hline & $2.52 \times 10^{7}$ & 12.348 & 0.145 & 1.174 & 12.302 & 0.157 & 1.276 \\
\hline
\end{tabular}

\section{Detection results of the clinical samples by the multiplex qRT-PCR}

A total of 424 clinical samples collected in Guangxi Province, Southern China from October 2018 to December 2020 were detected by the developed multiplex qRT-PCR for evaluate its practicality in the fields. As a result, the positive rates of ASFV, CSFV and APPV were $45.58 \%(232 / 509), 12.57 \%(64 / 509)$ and $3.54 \%$ (18/509), respectively, while the co-infection rates of ASFV and CSFV, ASFV and APPV, CSFV and APPV were $4.91 \%$ (25/509), $1.38 \%$ (7/509), $0.98 \%$ (5/509), respectively (Table 3). 
Table 3

Detection results of clinical samples by the multiplex qRT-PCR

\begin{tabular}{|c|c|c|c|c|c|c|c|}
\hline Date & Numbers & ASFV (\%) & $\operatorname{CSFV}(\%)$ & APPV (\%) & $\begin{array}{l}\text { ASFV+ } \\
\text { CSFV (\%) }\end{array}$ & $\begin{array}{l}\text { ASFV + } \\
\text { APPV (\%) }\end{array}$ & $\begin{array}{l}\text { CSFV + } \\
\text { APPV (\%) }\end{array}$ \\
\hline $\begin{array}{l}\text { Oct, } \\
2018\end{array}$ & 18 & $0(0)$ & $2(11.11)$ & $1(5.56)$ & $0(0)$ & $0(0)$ & $0(0)$ \\
\hline $\begin{array}{l}\text { Nov, } \\
2018\end{array}$ & 40 & $0(0)$ & $9(22.5)$ & $4(10.00)$ & $0(0)$ & $0(0)$ & $1(2.50)$ \\
\hline $\begin{array}{l}\text { Dec, } \\
2018\end{array}$ & 30 & $5(16.67)$ & $6(20.00)$ & 1 (3.33) & $3(10.00)$ & $0(0)$ & 1 (3.33) \\
\hline $\begin{array}{l}\text { Jan, } \\
2019\end{array}$ & 38 & $5(13.16)$ & $4(10.53)$ & $0(0)$ & $1(2.63)$ & $0(0)$ & $0(0)$ \\
\hline $\begin{array}{l}\text { Feb, } \\
2019\end{array}$ & 57 & $15(26.32)$ & $5(8.77)$ & $3(5.26)$ & $3(5.26)$ & $2(3.51)$ & $1(1.75)$ \\
\hline $\begin{array}{l}\text { Mar, } \\
2019\end{array}$ & 36 & $10(27.78)$ & $7(19.44)$ & $0(0)$ & $4(11.11)$ & $0(0)$ & $0(0)$ \\
\hline $\begin{array}{l}\text { Apr, } \\
2019\end{array}$ & 19 & $12(63.16)$ & $3(15.79)$ & $1(5.26)$ & $0(0)$ & $0(0)$ & $0(0)$ \\
\hline $\begin{array}{l}\text { May, } \\
2019\end{array}$ & 16 & $16(100.00)$ & $0(0)$ & $2(12.50)$ & $0(0)$ & $1(6.25)$ & $0(0)$ \\
\hline $\begin{array}{l}\text { Jun, } \\
2019\end{array}$ & 11 & $4(36.36)$ & 1 (9.09) & 1 (9.09) & $0(0)$ & $0(0)$ & $0(0)$ \\
\hline $\begin{array}{l}\text { Jul, } \\
2019\end{array}$ & 12 & $12(100.00)$ & $2(16.67)$ & $0(0)$ & $0(0)$ & $0(0)$ & $0(0)$ \\
\hline $\begin{array}{l}\text { Aug, } \\
2019\end{array}$ & 28 & $20(71.43)$ & $2(7.14)$ & $0(0)$ & $2(7.14)$ & $0(0)$ & $0(0)$ \\
\hline $\begin{array}{l}\text { Sep, } \\
2019\end{array}$ & 15 & $15(100.00)$ & $2(13.33)$ & $0(0)$ & $2(13.33)$ & $0(0)$ & $0(0)$ \\
\hline $\begin{array}{l}\text { Oct, } \\
2019\end{array}$ & 20 & $20(100.00)$ & $1(5.00)$ & $0(0)$ & $1(5.00)$ & $0(0)$ & $0(0)$ \\
\hline $\begin{array}{l}\text { Nov, } \\
2019\end{array}$ & 24 & $21(87.50)$ & $5(20.83)$ & $3(12.50)$ & $5(20.83)$ & $3(12.50)$ & 2 (8.33) \\
\hline $\begin{array}{l}\text { Dec, } \\
2019\end{array}$ & 10 & $6(60.00)$ & $1(10.00)$ & $0(0)$ & $0(0)$ & $0(0)$ & $0(0)$ \\
\hline $\begin{array}{l}\text { Jan, } \\
2020\end{array}$ & 10 & $10(100.00)$ & $0(0)$ & $0(0)$ & $0(0)$ & $0(0)$ & $0(0)$ \\
\hline $\begin{array}{l}\text { Feb, } \\
2020\end{array}$ & 10 & $7(70.00)$ & $1(10.00)$ & $0(0)$ & $0(0)$ & $0(0)$ & $0(0)$ \\
\hline
\end{tabular}




\begin{tabular}{|llllllll|}
\hline Date & Numbers & ASFV (\%) & CSFV (\%) & APPV (\%) & $\begin{array}{l}\text { ASFV+ } \\
\text { CSFV (\%) }\end{array}$ & $\begin{array}{l}\text { ASFV+ } \\
\text { APPV (\%) }\end{array}$ & $\begin{array}{l}\text { CSFV+ } \\
\text { APPV (\%) }\end{array}$ \\
\hline $\begin{array}{l}\text { Jul, } \\
2020\end{array}$ & 4 & $0(0)$ & $4(100.00)$ & $0(0)$ & $0(0)$ & $0(0)$ & $0(0)$ \\
\hline $\begin{array}{l}\text { Aug, } \\
2020\end{array}$ & 10 & $8(80.00)$ & $0(0)$ & $0(0)$ & $0(0)$ & $0(0)$ & $0(0)$ \\
$\begin{array}{l}\text { Sep, } \\
2020\end{array}$ & 26 & $14(53.85)$ & $2(7.69)$ & $0(0)$ & $0(0)$ & $0(0)$ & $0(0)$ \\
\hline $\begin{array}{l}\text { Oct, } \\
2020\end{array}$ & 20 & $13(65.00)$ & $6(30.00)$ & $0(0)$ & $4(20.00)$ & $0(0)$ & $0(0)$ \\
\hline $\begin{array}{l}\text { Nov, } \\
2020\end{array}$ & 32 & $15(46.88)$ & $1(3.13)$ & $0(0)$ & $0(0)$ & $0(0)$ & $0(0)$ \\
\hline $\begin{array}{l}\text { Dec, } \\
2020\end{array}$ & 23 & $4(17.39)$ & $0(0)$ & $2(8.70)$ & $0(0)$ & $0(0)$ & $0(0)$ \\
\hline \begin{tabular}{l} 
Total \\
\hline
\end{tabular} & $\mathbf{5 0 9}$ & $\mathbf{2 3 2 ( 4 5 . 5 8 )}$ & $\mathbf{6 4 ( 1 2 . 5 7 )}$ & $\mathbf{1 8 ( 3 . 5 4 )}$ & $\mathbf{2 5 ( 4 . 9 1 )}$ & $\mathbf{7 ( 1 . 3 8 )}$ & $\mathbf{5 ( 0 . 9 8 )}$ \\
\hline
\end{tabular}

\section{Phylogenetic analysis based on ASFV p72 gene}

A total of 21 clinical samples were selected randomly from ASFV positive samples and partial p72 gene of ASFV were amplified and sequenced. Phylogenetic analysis based on partial p72 gene nucleotide sequences showed that 17 strains of the 21 strains obtained from Guangxi Province, together with strains from Mozambique (MOZ-60-98, MAD/1/98, MAZ 9/2006), Tanzania (TAN 2011/01) and Zambia (LUS931), formed a distinguishable cluster belonging to genotype II, and the other 4 strains, together with strains from Nigeria (Nig01, NIG-2), Angola (Ang72), Congo (Kat67), Ghana (GHA/1/00), South Africa (ZAR85) and Cameroon (CAM/4/85), belonged to genotype I (Fig. 4).

\section{Discussion}

ASFV and CSFV might co-infect in pig herds and their clinical manifestations and pathological changes might be hard to distinguish in the fields, so as CSFV and APPV $[2,8,15,16]$. Since there exist coinfection and/or secondary infection of ASFV, CSFV and APPV in certain pig herds $[18,19]$, it is necessary to differentially detect these pathogens in the laboratory to accurately diagnose these diseases. The qRTPCR is a rapid, specific, sensitive and accurate method for detection of viral nucleic acids, which could be conveniently used for quantification and detection of swine viral pathogens $[27,28]$. Due to its high throughput, sensitivity, accuracy and ability to detect several pathogens with one reaction in very short time, multiplex qRT-PCR has been widely used in veterinary diagnostic laboratory in China. Therefore, a one-step multiplex qRT-PCR was developed in order to differentially detect ASFV, CSFV and APPV in this study. The assay could specifically detect ASFV, CSFV and APPV with a detection limit of $2.52 \times 10^{1}$ copies $/ \mu \mathrm{L}$ for each pathogen, and the coefficients of variation of the intra- and inter-assay were all less than $2 \%$, showing high specificity, sensitivity and repeatability. Finally, the developed assay was used to detect 424 clinical samples to further verify its practicability in the fields. 
The developed qRT-PCR was used to detect 509 clinical samples from Guangxi Province, Southern China for ASFV, CSFV and APPV. As a result, the positive rates of ASFV, CSFV and APPV were $45.58 \%, 12.57 \%$ and $3.54 \%$, respectively, indicating that ASFV, CSFV and APPV were widely popular in the pig herds in Southern China. Furthermore, it was noteworthy that the co-infection rates of ASFV/CSFV, ASFV/APPV and CSFV/APPV were $4.91 \%, 1.38 \%$ and $0.98 \%$, respectively, indicating that co-infections of ASFV, CSFV and APPV were common in pig herds to a certain extent. The results were similar to our previous report on the detection of ASFV, CSFV and APPV in the fields [19]. Since ASFV and CSFV co-infection could exacerbate the manifestations and pathological changes each other [18], and ASFV could suppress the immune response of pig herds which vaccinated with CSFV vaccine [29], it is very important to accurately detect the pathogens and rapidly eliminate the infected pigs in the early stage. Therefore, the developed multiplex qRT-PCR in this study could provide a useful tool for rapid differential detection of ASFV, CSFV and APPV in the fields.

ASF was firstly outbroke in China in August 2018, and then outbroke in other Asian countries [30], which caused huge economic losses to the swine industry. Since ASF was a newly emergent disease in China and has spread rapidly across this country [6], it is very interested to study the genomic characteristics of ASFV. The ASFV genome varies about 170 to $193 \mathrm{~kb}$, which encodes for 150 to 167 proteins [31]. Based on partial p72 gene sequences, ASFV is currently classified into 24 genotypes and divided into three lineages [32], and 21 ASFV strains from Guangxi Province in this study shared a high level of nucleotide homology with $97.3 \% \sim 100 \%$, and shared $83.4 \%$ 95.1\% nucleotide identity with strains from different countries in the world (data not showed). Phylogenetic analysis based on partial p72 gene sequences revealed that all ASFV strains from Guangxi Province belonged to two genotypes (genotype I and II), of which most strains were grouped into Genotype II and the other strains were grouped into genotype I. The results showed that genotype I and II ASFV strains were popular in Guangxi Province at the same time, which increased the complexity of pandemic strains and made it harder to prevent and control. Furthermore, genotype II ASFV strains may enable domestic pigs and wild boars to develop chronic infections and become carriers after recovery [30]. Since genotype II were the mainly popular strains in Guangxi Province, it is necessary to pay more attention to this phenomenon.

\section{Conclusion}

This is the first report on a one-step multiplex qRT-PCR, which indicated high sensitivity, specificity and repeatability, to provide an accurate tool for simultaneous and differential detection of ASFV, CSFV and APPV. The ASFV strains from Guangxi Province, Southern China belonged to genotype I and II.

\section{Methods}

\section{Viruses and clinical samples}

CSFV (C vaccine strain), PCV2 (SX07 vaccine strain), PRRSV (TJM-F92 vaccine strain), FMDV (O/Mya98/XJ/2010 vaccine strain), PRV (Bartha-K61 vaccine strain), PPV ( $N$ vaccine strain), PEDV 
(CV777 vaccine strain), TGEV (H vaccine strain), PRoV (NX vaccine strain) were stored in our laboratory. The ASFV, APPV, BVDV-1, BVDV-2, BDV and PDCoV positive clinical samples were collected in the fields, confirmed by PCR/RT-PCR and gene sequencing, and stored in our laboratory.

A total of 509 clinical samples, including brain, lung, liver, spleen and lymph nodes for each naturally dead pig, were collected from different pig herds in Guangxi Province, Southern China from October 2018 to December 2020. All clinical samples were stored at $-80^{\circ} \mathrm{C}$ until used.

\section{Primers and TaqMan probes}

Three pairs of specific primers and TaqMan probes used for multiplex qRT-PCR assay were designed using software Primer Express 3.0 basing on the genomic sequences of ASFV (GenBank accession number NC_001659), CSFV (NC_002657) and APPV (KY624591), respectively, which amplified 79 bp fragment for ASFV p72 gene, 72 bp fragment for CSFV 5'UTR and 90 bp fragment for APPV 5'UTR, respectively. The detailed information of primers and probes were listed in Table 1.

\section{Table 1 Primers and probes used for detection of ASFV, CSFV and APPV}

\begin{tabular}{ccc}
\hline Primer and probe & Sequence $\left(5 ' \rightarrow 3^{\prime}\right)$ & Product size $(\mathrm{bp})$ \\
\hline ASFV-p72-F & GGCGTATAAAAAGTCCAGGAAATTC \\
ASFV-p72-R & TTCGGCGAGCGCTTTATC & 79 \\
ASFV-p72-P & Texas Red-TCACCAAATCCTTTTGCGATGCAAGCT-BHQ2 \\
CSFV-5'UTR-F & CCTGAGTACAGGACAGTCGTCAGT & 72 \\
CSFV-5'UTR-R & CCCTCGTCCACATAGCATCTC \\
CSFV-5'UTR-P & JOE-TTCGACGTGAGCAGAAGCCCACC-BHQ1 \\
APPV-5'UTR-F & GGCGTGCCCAAAGAGAAAT & \\
APPV-5'UTR-R & GGCACTCTATCAAGCAGTAAGGTCTA & 90 \\
APPV-5'UTR-P & FAM-TCGGGTCCACCATGCCCCTTT-BHQ1 \\
\hline
\end{tabular}

\section{Extraction of nucleic acid}

All vaccine viruses and the pooled clinical tissue homogenates $(20 \%, \mathrm{~W} / \mathrm{V})$ were resuspended with phosphate buffer saline (PBS, pH7.2), vortexed and centrifuged at $12,000 \times \mathrm{g}$ at $4^{\circ} \mathrm{C}$ for $5 \mathrm{~min}$. Total RNA and DNA was extracted from the supernatants using MiniBEST RNA/DNA Extraction Kit Ver.5.0 (TaKaRa, Dalian, China) according to the manufacture's instructions, and stored at $-80^{\circ} \mathrm{C}$ until used. 
Total DNA was extracted from ASFV positive sample, and total RNA were extracted from CSFV vaccine and APPV positive sample and then reversed transcribed to CDNA. The target fragments of ASFV, CSFV and APPV were amplified by PCR using ASFV DNA and CSFV, APPV cDNA as templates. The amplicons were purified and cloned into pMD18-T vector (TaKaRa, Dalian, China) and transferred into E. coli DH5a competent cells (TaKaRa, Dalian, China). The positive clones were cultured at $37^{\circ} \mathrm{C}$ for $18 \mathrm{~h}-20 \mathrm{~h}$ and extracted by MiniBEST Plasmid Extraction Kit Ver.5.0 (TaKaRa, Dalian, China) for plasmid constructs. The plasmids were named as p-ASFV, p-CSFV and p-APPV, respectively, and stored at $-80^{\circ} \mathrm{C}$ until used as standard plasmids.

The standard plasmids were quantified by ultraviolet absorbance at $260 \mathrm{~nm}$ and $280 \mathrm{~nm}$ with a NanoDrop Sectrophotometer (Thermo Fisher, USA). The exact copy numbers of plasmids were calculated using the following formula:

Plasmid copies $/ \mu \mathrm{L}=\left(6.02 \times 10^{23}\right) \times\left(\mathrm{X} \mathrm{ng} / \mu \mathrm{L} \times 10^{-9}\right) /$ plasmid length $(\mathrm{bp}) \times 660$

\section{Optimization of the single qRT-PCR assay}

The standard plasmids were 10-fold serially diluted from $2.52 \times 10^{9}$ copies $/ \mu \mathrm{L}$ to $2.52 \times 10^{1}$ copies $/ \mu \mathrm{L}$ هfinal reaction concentrations: from $2.52 \times 10^{8}$ copies $/ \mu \mathrm{L}$ to $2.52 \times 10^{0}$ copies $/ \mu \mathrm{L} \otimes$ for optimizing the reaction conditions of the single qRT-PCR of ASFV, CSFV and APPV. A total volume of $20 \mu \mathrm{L}$ contained: $2 \times$ One Step qRT-PCR Buffer III (TaKaRa, Dalian, China) $10 \mu \mathrm{L}$, Ex Taq HS ( $5 \mathrm{U} / \mu \mathrm{L})$ (TaKaRa, Dalian, China) $0.4 \mu \mathrm{L}$, PrimeScript RT Enzyme Mix II (TaKaRa, Dalian, China) $0.4 \mu \mathrm{L}$, each primer 0.1-0.6 $\mu \mathrm{L}$, probe 0.1-0.6 $\mu \mathrm{L}$, plasmid template $2.0 \mu \mathrm{L}$ and distilled water to a total volume of $20 \mu \mathrm{L}$. All reactions were amplified by an ABI QuantStudio ${ }^{\mathrm{TM}} 6$ Real-time System (ABI, USA) and the amplification parameters were as follows: $42^{\circ} \mathrm{C}$ for $5 \mathrm{~min}$, followed by $95^{\circ} \mathrm{C}$ for $10 \mathrm{~s}$; then 40 cycles of $95^{\circ} \mathrm{C}$ for $5 \mathrm{~s}$ and $59^{\circ} \mathrm{C}$ for $34 \mathrm{~s}$. The fluorescent signals were determined at the end of each cycle.

\section{Optimization of the multiplex qRT-PCR assay}

Based on the optical reaction conditions of the single qRT-PCR, the reaction conditions of the multiplex qRT-PCR, imcluding annealing temperature, primer concentrations, probe concentrations and so on, were further determined by orthogonal experiments.

A total volume of $20 \mu \mathrm{L}$ contained: $10 \mu \mathrm{L}$ of $2 \times$ One Step qRT-PCR Buffer III (TaKaRa, Dalian, China), 0.4 $\mu \mathrm{L}$ of Ex Taq HS ( $5 \mathrm{U} / \mu \mathrm{L})$ (TaKaRa, Dalian, China), $0.4 \mu \mathrm{L}$ of PrimeScript RT Enzyme Mix II (TaKaRa, Dalian, China) , 0.1-0.6 $\mu \mathrm{L}$ of the mixtures of primers and probes with different final concentrations, 2.0 $\mu \mathrm{L}$ of the three standard plasmids mixed in ratio of 1:1:1 with different final concentrations as templates, and sterilized distilled water to a final volume of $20 \mu \mathrm{L}$. The amplification parameters were as follows: $42^{\circ} \mathrm{C}$ for $5 \mathrm{~min}$, followed by incubation at $95^{\circ} \mathrm{C}$ for $10 \mathrm{~s}$; then 40 cycles of denaturation at $95^{\circ} \mathrm{C}$ for $5 \mathrm{~s}$ and annealing and extension at $59^{\circ} \mathrm{C}$ for $34 \mathrm{~s}$. Finally, the fluorescent signals were determined at the end of each cycle. After amplification, a Ct value was assigned to each sample. The final concentrations of 
primers, probes and the amplification conditions were optimized to obtain the maximun $\Delta \mathrm{Rn}$ and minimal $\mathrm{C}_{t}$ using the standard plasmids of different dilutions as template.

\section{Specificity analysis of the multiplex qRT-PCR}

The DNA or RNA of ASFV, CSFV, APPV, PCV2, PRV, PRRSV, FMDV, PEDV, TGEV, PRoV, PDCoV, BVDV-1, BVDV-2 and BDV were used as templates of the developed multiplex qRT-PCR to verify the specificity of the assay.

\section{Sensitivity analysis of the multiplex qRT-PCR}

The standard plasmids of p-ASFV, p-CSFV and p-APPV were 10-fold serially diluted from $2.52 \times 10^{8}$ copies $/ \mu \mathrm{L}$ to $2.52 \times 10^{0}$ copies $/ \mu \mathrm{L} \otimes$ final reaction concentrations: from $2.52 \times 10^{7}$ copies $/ \mu \mathrm{L}$ to $2.52 \times 10^{-}$

${ }^{1}$ copies/ $\mu \mathrm{L} 囚$ and used as templates for the multiplex qRT-PCR to determine the sensitivity of the assay.

\section{Repeatability analysis of the multiplex qRT-PCR}

The standard plasmids of p-ASFV, p-CSFV and p-APPV were 10-fold serially diluted from $2.52 \times 10^{8}$ copies $/ \mu \mathrm{L}$ to $2.52 \times 10^{0}$ copies $/ \mu \mathrm{L}$, and the concentrations of $2.52 \times 10^{8}$ copies $/ \mu \mathrm{L}, 2.52 \times 10^{6} \mathrm{copies} / \mu \mathrm{L}$ and $2.52 \times 10^{4}$ copies $/ \mu \mathrm{L} \otimes$ final reaction concentrations: $2.52 \times 10^{7}$ copies $/ \mu \mathrm{L}, 2.52 \times 10^{5}$ copies $/ \mu \mathrm{L}$ and $2.52 \times 10^{3}$ copies $/ \mu \mathrm{L} \otimes$ were used as templates for the developed multiplex qRT-PCR. The coefficients of variation of the intra- and inter-assay were determined to evaluate the repeatability of the assay.

\section{Detection of clinical samples by the multiplex qRT-PCR}

A total of 509 clinical samples were collected from pig farms in Guangxi Province, Southern China from October 2018 to December 2020. The total RNA and DNA were extracted from $20 \%$ tissue supernatants using MiniBEST RNA/DNA Extraction Kit Ver.5.0 (TaKaRa, Dalian, China) and were detected by the developed multiplex qRT-PCR for ASFV, CSFV and APPV.

\section{Phylogenetic analysis based on ASFV p72 gene}

Twenty-one samples were selected randomly from the positive samples of ASFV to amplify partial p72 gene using a pair of primers (P72-U: 5'-GGCACAAGTTCGGACATGT-3', P72-D: 5'-

GTACTGTAACGCAGCACAG-3') as previously described [33]. The PCR products were purified, ligated to pMD-18T vector (TaKaRa, Dalian, China) and transferred to E. coli. DH5a competent cells. The positive clones were selected and sequenced (TaKaRa, Dalian, China), and the acquired sequences were edited by the EditSeq program of the DNAstar software, and aligned with the reference strains retrieved from GenBank using Clustal W. Phylogenetic reconstruction was conducted using the Maximum-Likelihood algorithm method $(T 92+G)$. Phylogenetic tree reliability was supported using the Kimura distances and a bootstrap method with 1000 replications. 


\section{Abbreviations}

APPV: atypical porcine pestivirus; ASFV: African swine fever virus; BDV: border disease virus; BVDV: bovine viral diarrhea virus; CSFV: classical swine fever virus; CV: Coefficient of variation; FMDV: foot-andmouth disease virus; multiplex qRT-PCR: multiplex real-time quantitative RT-PCR; OIE: The World Organization for Animal Health; PCV2: porcine circovirus type 2; PDCoV: porcine deltacoronavirus; PEDV: porcine epidemic diarrhea virus; PPV: porcine parvovirus; PRRSV: porcine reproductive and respiratory syndrome virus; PRV: pseudorabies virus; TGEV: transmissible gastroenteritis virus; PRoV: porcine rotavirus; RT-PCR: reverse-transcription polymerase chain reaction.

\section{Declarations}

\section{Acknowledgements}

We are grateful to Guangxi Center for Animal Disease Control and Prevention (CADC) for providing all the viral strains and clinical samples used in this study. Guangxi CADC was approved by Ministry of Agriculture and Rural Affairs of the People's Republic of China for collection and detection of ASFV in clinical samples (Approval number: 2018-154-25).

\section{Authors' contributions}

LHX carried out the experiments, data analysis and drafted the manuscript. SKC initiated the research program, and contributed to manuscript revision and final presentation. ZJ and CYT helped to perform the experiments. YYW and LWJ participated in sample collection. SHB revised the manuscript. QSJ and LF participated in clinical data acquisition. All authors have read and approved the final manuscript.

\section{Funding}

This work was supported by Guangxi Science and Technology Bureau, China (AA17204057) and Guangxi Agricultural and Rural Bureau, China (Z201954, Z202031). The funding sources had no involvement in the design of the research, the collection, analysis and interpretation of data, and the writing of the manuscript.

\section{Availability of data and materials}

All data generated or analyzed during this study are included in this article and are available from the corresponding author on reasonable request.

\section{Ethics approval and consent to participate}

The programs and procedures used in this study have been examined and approved by Guangxi CADC, China. We obtained written informed consent to use the clinical samples in our study from the owners of the animals. 


\section{Consent for publication}

Not applicable.

\section{Competing interests}

The authors declare that they have no competing interests.

\section{Author details}

${ }^{1}$ College of Animal Science and Technology, Guangxi University, Nanning City 530005, Guangxi Province, China

${ }^{2}$ Guangxi Center for Animal Disease Control and Prevention, Nanning City 530001, Guangxi Province, China

\section{References}

1. Alonso C, Borca M, Dixon L, Revilla Y, Rodriguez F, Escribano JM, et al. ICTV Virus Taxonomy Profile: Asfarviridae. J Gen Virol. 2018;99(5):613-4.

2. Dixon LK, Sun H, Roberts H. African swine fever. Antiviral Res. 2019;165:34-41.

3. Cwynar P, Stojkov J, Wlazlak K. African Swine Fever Status in Europe. Viruses. 2019;11(4).

4. Sanchez-Vizcaino JM, Mur L, Martinez-Lopez B. African swine fever: an epidemiological update. Transbound Emerg Dis. 2012;59 Suppl 1:27-35.

5. Zhou X, Li N, Luo Y, Liu Y, Miao F, Chen T, et al. Emergence of African Swine Fever in China, 2018. Transbound Emerg Dis. 2018;65(6):1482-4.

6. Tao D, Sun D, Liu Y, Wei S, Yang Z, An T, et al. One year of African swine fever outbreak in China. Acta Trop. 2020;211:105602.

7. Brown VR, Bevins SN. A Review of classical swine fever virus and routes of introduction into the United States and the potential for virus establishment. Front Vet Sci. 2018;5:31.

8. Smith DB, Meyers G, Bukh J, Gould EA, Monath T, Scott Muerhoff A, et al. Proposed revision to the taxonomy of the genus Pestivirus, family Flaviviridae. J Gen Virol. 2017;98(8):2106-12.

9. Coronado L, Perera CL, Rios L, Frias MT, Perez LJ. A critical review about different vaccines against classical swine fever virus and their repercussions in endemic regions. Vaccines (Basel). 2021;9(2).

10. Ganges L, Crooke HR, Bohorquez JA, Postel A, Sakoda Y, Becher P, et al. Classical swine fever virus: the past, present and future. Virus Res. 2020;289:198151.

11. Luo Y, Ji S, Lei JL, Xiang GT, Liu Y, Gao Y, et al. Efficacy evaluation of the C-strain-based vaccines against the subgenotype $2.1 \mathrm{~d}$ classical swine fever virus emerging in China. Vet Microbiol. 2017;201:154-61.

12. Zhou B. Classical swine fever in China-An update minireview. Front Vet Sci. 2019;6:187. 
13. Gatto IRH, Sonalio K, de Oliveira LG. Atypical porcine pestivirus (APPV) as a new species of Pestivirus in pig production. Front Vet Sci. 2019;6:35.

14. Hause BM, Collin EA, Peddireddi L, Yuan F, Chen Z, Hesse RA, et al. Discovery of a novel putative atypical porcine pestivirus in pigs in the USA. J Gen Virol. 2015;96(10):2994-8.

15. Pan S, Mou C, Chen Z. An emerging novel virus: Atypical porcine pestivirus (APPV). Rev Med Virol. 2019;29(1):e2018.

16. de Groof A, Deijs M, Guelen L, van Grinsven L, van Os-Galdos L, Vogels W, et al. Atypical porcine pestivirus: A possible cause of congenital tremor type A-II in newborn piglets. Viruses. 2016;8(10).

17. Bradley R, Done JT, Hebert CN, Overby E, Askaa J, Basse A, et al. Congenital tremor type Al: light and electron microscopical observations on the spinal cords of affected piglets. J Comp Pathol. 1983;93(1):43-59.

18. Cabezon O, Munoz-Gonzalez S, Colom-Cadena A, Perez-Simo M, Rosell R, Lavin S, et al. African swine fever virus infection in classical swine fever subclinically infected wild boars. BMC Vet Res. 2017;13(1):227.

19. Liu H, Shi K, Sun W, Zhao J, Yin Y, Si H, et al. Development a multiplex RT-PCR assay for simultaneous detection of African swine fever virus, classical swine fever virus and atypical porcine pestivirus. J Virol Methods. 2021;287:114006.

20. Aguero M, Fernandez J, Romero L, Sanchez Mascaraque C, Arias M, Sanchez-Vizcaino JM. Highly sensitive PCR assay for routine diagnosis of African swine fever virus in clinical samples. J Clin Microbiol. 2003;41(9):4431-4.

21. Tignon M, Gallardo C, Iscaro C, Hutet E, Van der Stede $Y$, Kolbasov D, et al. Development and interlaboratory validation study of an improved new real-time PCR assay with internal control for detection and laboratory diagnosis of African swine fever virus. J Virol Methods. 2011;178(1-2):16170.

22. Hoffmann B, Beer M, Schelp C, Schirrmeier H, Depner K. Validation of a real-time RT-PCR assay for sensitive and specific detection of classical swine fever. J Virol Methods. 2005;130(1-2):36-44.

23. Ophuis RJ, Morrissy CJ, Boyle DB. Detection and quantitative pathogenesis study of classical swine fever virus using a real time RT-PCR assay. J Virol Methods. 2006;131(1):78-85.

24. Chen F, Knutson TP, Braun E, Jiang Y, Rossow S, Marthaler DG. Semi-quantitative duplex RT-PCR reveals the low occurrence of porcine pegivirus and atypical porcine pestivirus in diagnostic samples from the United States. Transbound Emerg Dis. 2019;66(3):1420-5.

25. Grau FR, Schroeder ME, Mulhern EL, Mclntosh MT, Bounpheng MA. Detection of African swine fever, classical swine fever, and foot-and-mouth disease viruses in swine oral fluids by multiplex reverse transcription real-time polymerase chain reaction. J Vet Diagn Invest. 2015;27(2):140-9.

26. Haines FJ, Hofmann MA, King DP, Drew TW, Crooke HR. Development and validation of a multiplex, real-time RT PCR assay for the simultaneous detection of classical and African swine fever viruses. PLoS One. 2013;8(7):e71019. 
27. Hawkins SFC, Guest PC. Multiplex analyses using real-time quantitative PCR. Methods Mol Biol. 2017;1546:125-33.

28. Hoffmann B, Beer M, Reid SM, Mertens P, Oura CA, van Rijn PA, et al. A review of RT-PCR technologies used in veterinary virology and disease control: sensitive and specific diagnosis of five livestock diseases notifiable to the World Organisation for Animal Health. Vet Microbiol. 2009;139(1-2):1-23.

29. Gallardo C, Sanchez EG, Perez-Nunez D, Nogal M, de Leon P, Carrascosa AL, et al. African swine fever virus (ASFV) protection mediated by NH/P68 and NH/P68 recombinant live-attenuated viruses. Vaccine. 2018;36(19):2694-704.

30. Mighell E, Ward MP. African Swine Fever spread across Asia, 2018-2019. Transbound Emerg Dis. 2021. doi: 10.1111/tbed.14039.

31. de Villiers EP, Gallardo C, Arias M, da Silva M, Upton C, Martin R, et al. Phylogenomic analysis of 11 complete African swine fever virus genome sequences. Virology. 2010;400(1):128-36.

32. Giammarioli M, Gallardo C, Oggiano A, Iscaro C, Nieto R, Pellegrini C, et al. Genetic characterisation of African swine fever viruses from recent and historical outbreaks in Sardinia (1978-2009). Virus Genes. 2011;42(3):377-87.

33. Bastos AD, Penrith ML, Cruciere C, Edrich JL, Hutchings G, Roger F, et al. Genotyping field strains of African swine fever virus by partial p72 gene characterisation. Arch Virol. 2003;148(4):693-706.

\section{Figures}

Standard Curve

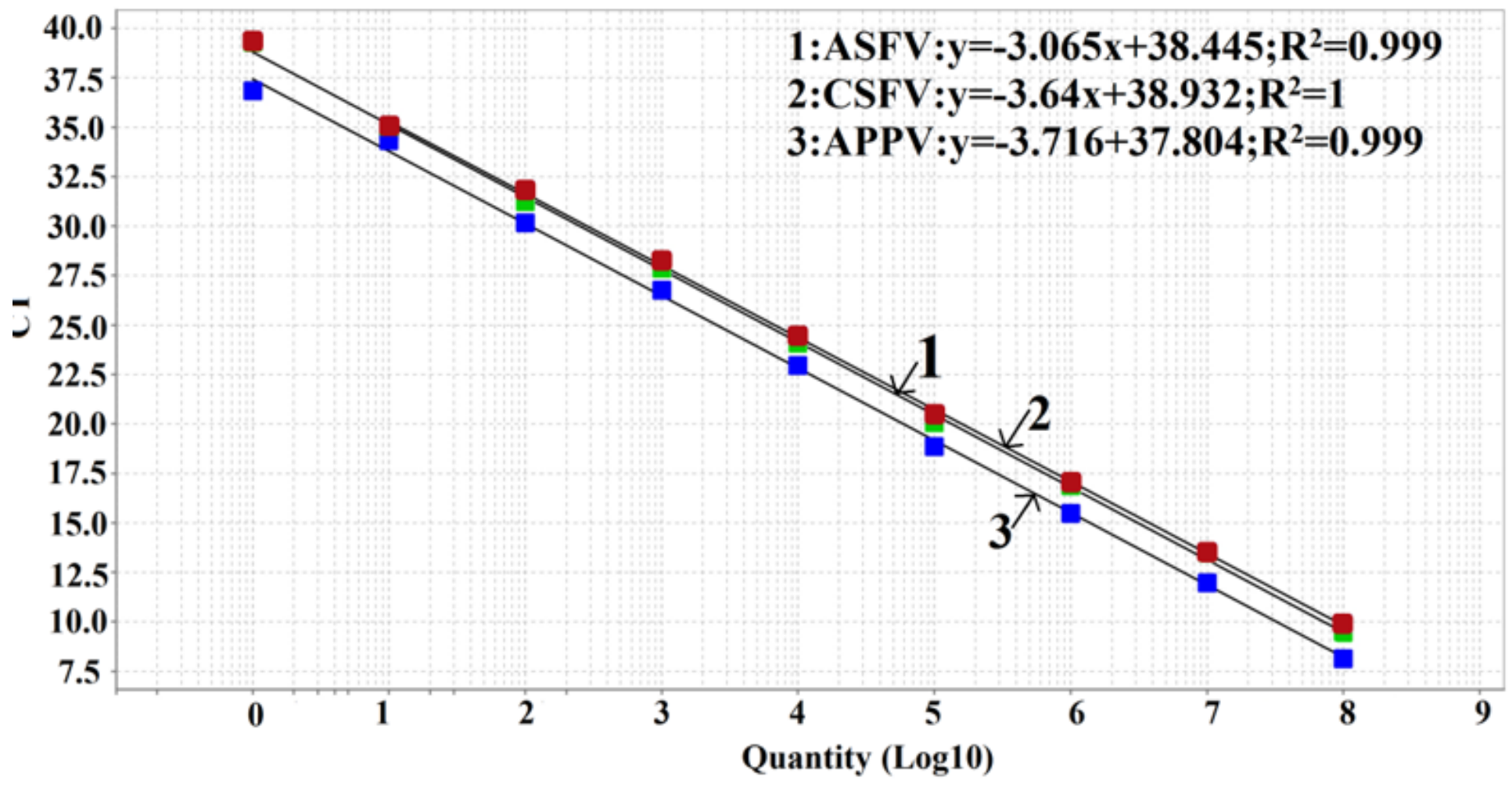


Figure 1

Standard curves of the multiplex qRT-PCR

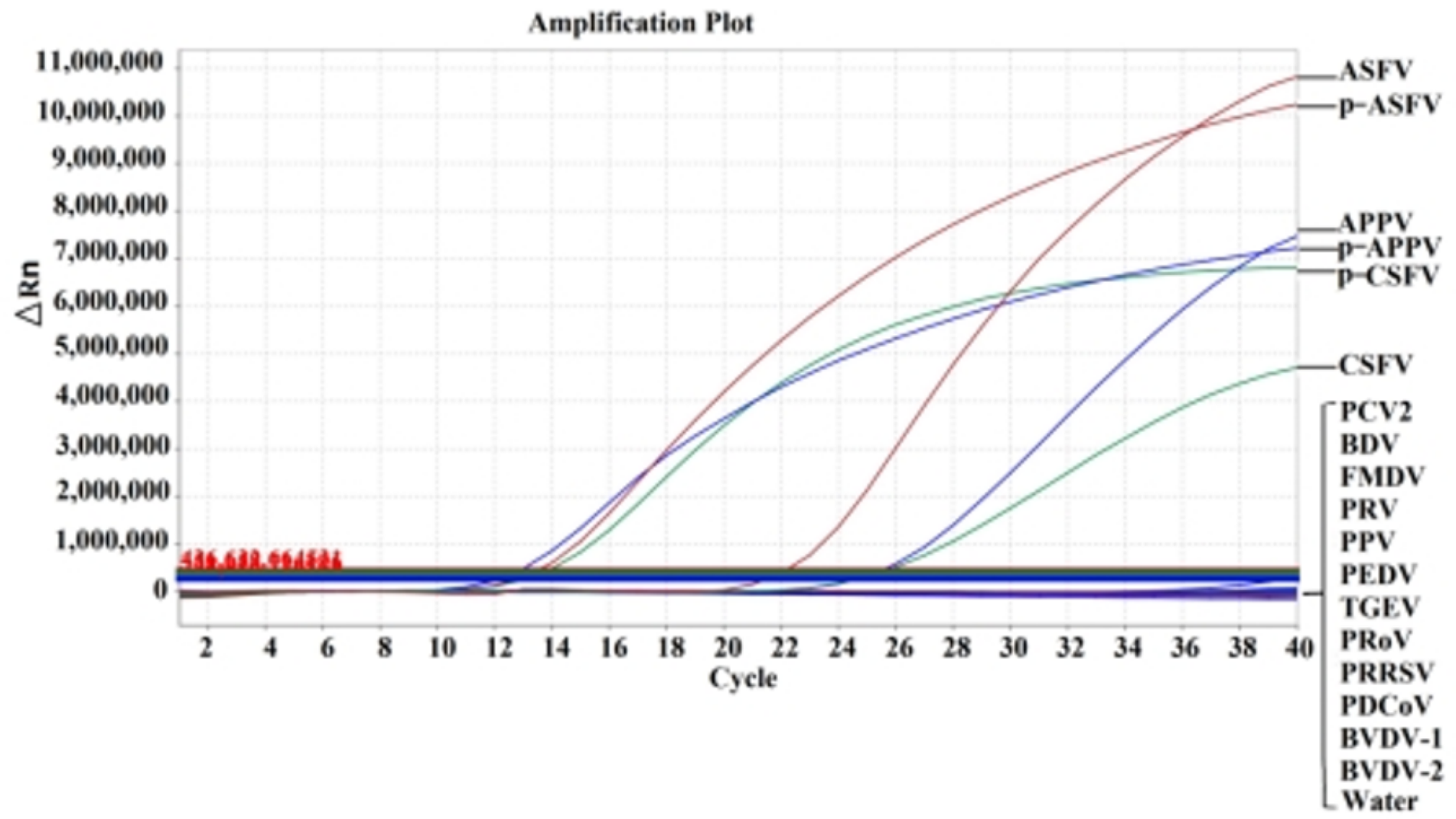

Figure 2

Specificity analysis of the multiplex qRT-PCR
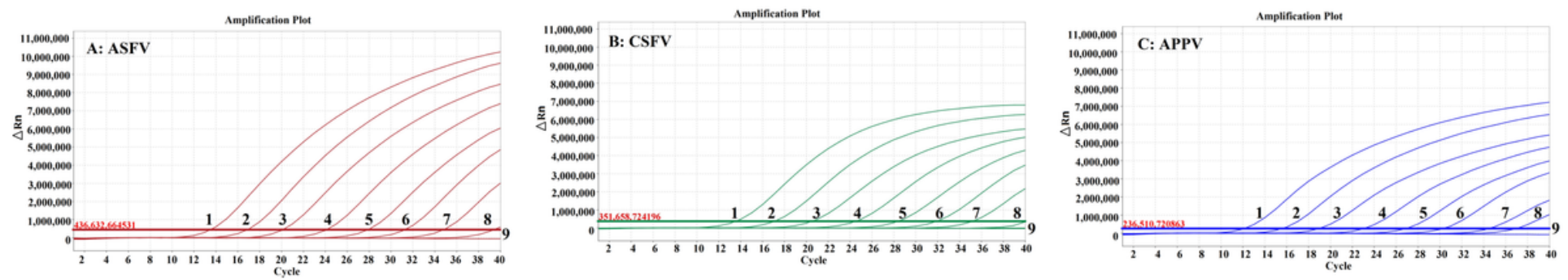

\section{Figure 3}

Sensitivity analysis of the multiplex qRT-PCR 1 9: $2.52 \times 107$ copies/ $\mu \mathrm{L} \sim 2.52 \times 10-1$ copies $/ \mu \mathrm{L}$ (final reaction concentrations) 


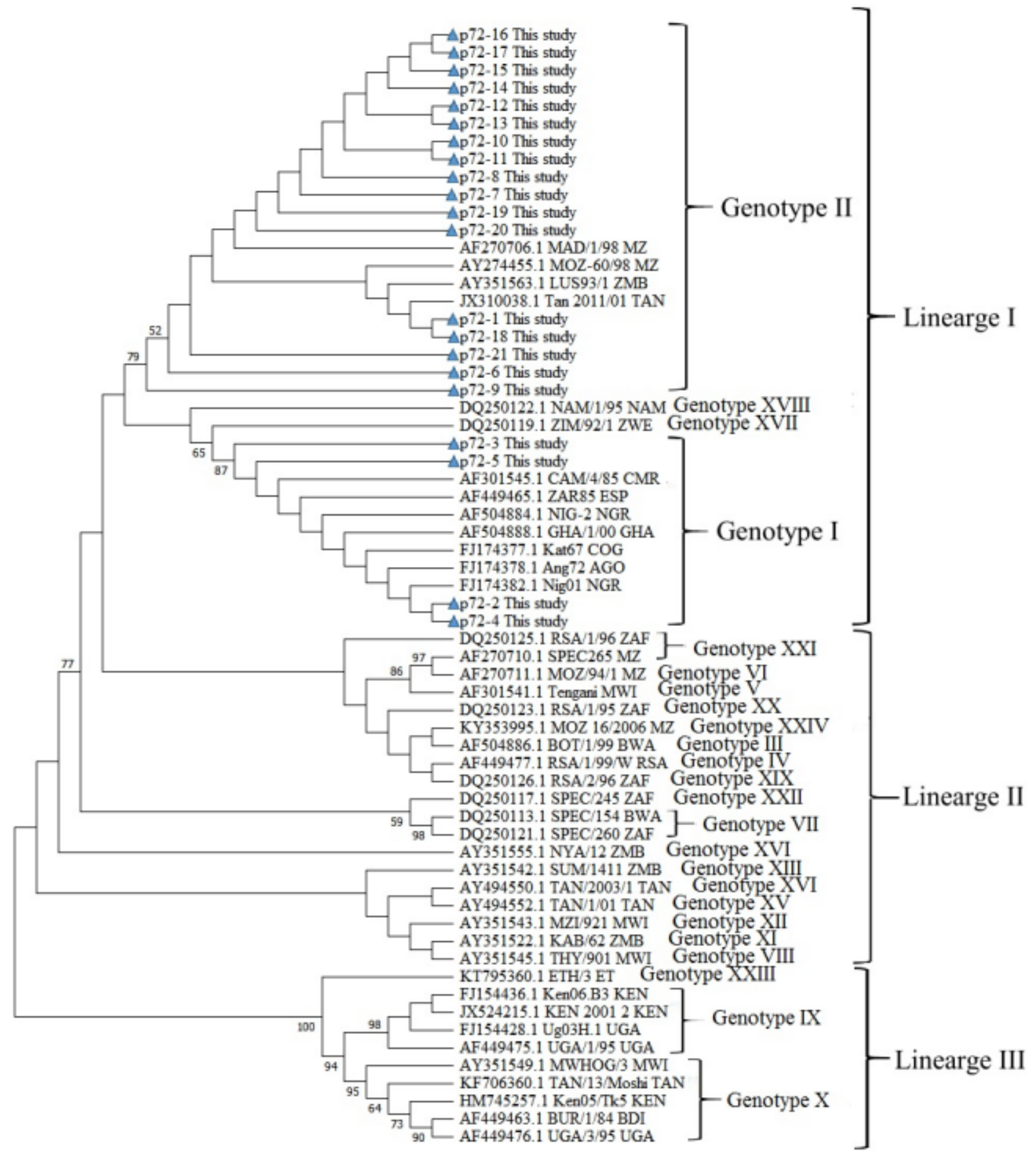

Figure 4

Phylogenetic tree based on partial p72 gene of ASFV 